\title{
ESTIMATION OF TRANSPIRATION OF THE 'VALENCIA' ORANGE YOUNG PLANT USING THERMAL DISSIPATION PROBE METHOD
}

\section{RUBENS D. COELHO ${ }^{1}$, LUCAS M. VELLAME ${ }^{2}$, EUSÍMIO F. FRAGA JÚNIOR ${ }^{3}$}

\begin{abstract}
Most studies on measures of transpiration of plants, especially woody fruit, relies on methods of heat supply in the trunk. This study aimed to calibrate the Thermal Dissipation Probe Method (TDP) to estimate the transpiration, study the effects of natural thermal gradients and determine the relation between outside diameter and area of xylem in 'Valencia' orange young plants. TDP were installed in 40 orange plants of 15 months old, planted in boxes of $500 \mathrm{~L}$, in a greenhouse. It was tested the correction of the natural thermal differences (DTN) for the estimation based on two unheated probes. The area of the conductive section was related to the outside diameter of the stem by means of polynomial regression. The equation for estimation of sap flow was calibrated having as standard lysimeter measures of a representative plant. The angular coefficient of the equation for estimating sap flow was adjusted by minimizing the absolute deviation between the sap flow and daily transpiration measured by lysimeter. Based on these results, it was concluded that the method of TDP, adjusting the original calibration and correction of the DTN, was effective in transpiration assessment.
\end{abstract}

KEYWORDS: lysimetry, sap flow, xylem.

\section{MÉTODO DE DISSIPAÇÃo TÉRMICA PARA A ESTIMATIVA DA TRANSPIRAÇÃO DE PLANTAS JOVENS DE LARANJEIRA 'VALÊNCIA'}

RESUMO: Grande parte dos estudos sobre medidas de transpiração de plantas, principalmente em frutíferas lenhosas, baseia-se em métodos de fornecimento de calor ao tronco. Este trabalho teve como objetivo calibrar o método da sonda de dissipação térmica (SDT) para a estimativa da transpiração, estudar os efeitos dos gradientes térmicos naturais e determinar a relação entre diâmetro externo e área do xilema em plantas jovens de laranjeira 'Valência'. Foram instaladas SDT em 40 plantas de laranjeira de 15 meses de idade, plantadas em caixas de $500 \mathrm{~L}$, em estufa. Foi testada a correção das diferenças térmicas naturais (DTN) pela estimativa com base em duas sondas não aquecidas. $\mathrm{A}$ área da secção condutora foi relacionada com o diâmetro externo do caule por meio de regressão polinomial. A equação para a estimativa do fluxo de seiva foi calibrada tendo como padrão medidas lisimétricas em uma planta representativa. $\mathrm{O}$ coeficiente angular da equação de estimativa do fluxo de seiva foi ajustado pela minimização dos desvios absolutos entre o fluxo de seiva e a transpiração diária medida pelo lisímetro. Conclui-se com base nos resultados que o método da SDT, com ajuste da calibração original e correção das DTNs, mostrou-se eficaz na avaliação da transpiração.

PALAVRAS-CHAVE: lisimetria, fluxo de seiva, xilema.

\section{INTRODUCTION}

Methods of measuring sap flow allow following, in a time scale of short intervals, the operation of water plants in their natural environment and undisturbed conditions for extended periods. Most studies on measures of transpiration of woody fruit plants mainly rely on methods of heat supply to the trunk. The estimation of transpiration based on these methods assumes the equivalence between the sap flow in the trunk and the transpiratory flow at the leaf surface, valid

\footnotetext{
${ }^{1}$ Eng $^{\circ}$ Agrônomo, Professor, ESALQ-USP, Piracicaba - SP, rdcoelho@esalq.usp.br.

${ }^{2}$ Eng $^{\mathrm{O}}$ Agrônomo, Professor Doutor, IF Sertão, Ouricuri - PE, lucasvellame@ gmail.com.

${ }^{3}$ Eng ${ }^{\text {O }}$ Agrônomo, Doutorando em Ciências, ESALQ-USP, Piracicaba - SP, eusimio@gmail.com.

Recebido pelo Conselho Editorial em: 8-11-2010

Aprovado pelo Conselho Editorial em: 28-12-2011
} 
assumption when considering the flow on a daily scale (VELLAME et al., 2010; SUGIURA et al. 2009; VELLAME et al., 2009; SANTOS et al., 1999; COELHO FILHO et al., 2005; DELGADOROJAS et al., 2007).

For the Thermal Dissipation Probe Method (TDP), the major sources of error are related to determining the sap conductive section area, the spatial distribution of flow in the stem, and the presence of natural thermal gradients present in the trunk.

This study aimed to calibrate the method TDP to estimate transpiration, study the effects of natural thermal gradients and determine the relation between outside diameter and area of xylem in young plants of 'Valencia' orange.

\section{MATERIAL AND METHODS}

The experiment was conducted on condition of protected environment (greenhouse covered with plastic film), in the Department of Biosystems Engineering of ESALQ/USP. It was evaluated the transpiration of 40 plants of 'Valencia' orange of 15 months old planted in cement boxes with dimensions of $0.92 \mathrm{~m}$ wide, $1.08 \mathrm{~m}$ long and $0.65 \mathrm{~m}$ high. To control the drain, a PVC pipe of $25 \mathrm{~mm}$ of nominal diameter has been installed, coated and drilled at the bottom by the same blanket buried vertically in the ground and serving as access tube in the event of excessive application of water.

\section{Operating principle}

Each sensor consists of a heated probe to constant power (Tc) and of an unheated probe ( $\mathrm{Tb}$ reference probe), both having an internal thermocouple (Figure 1).

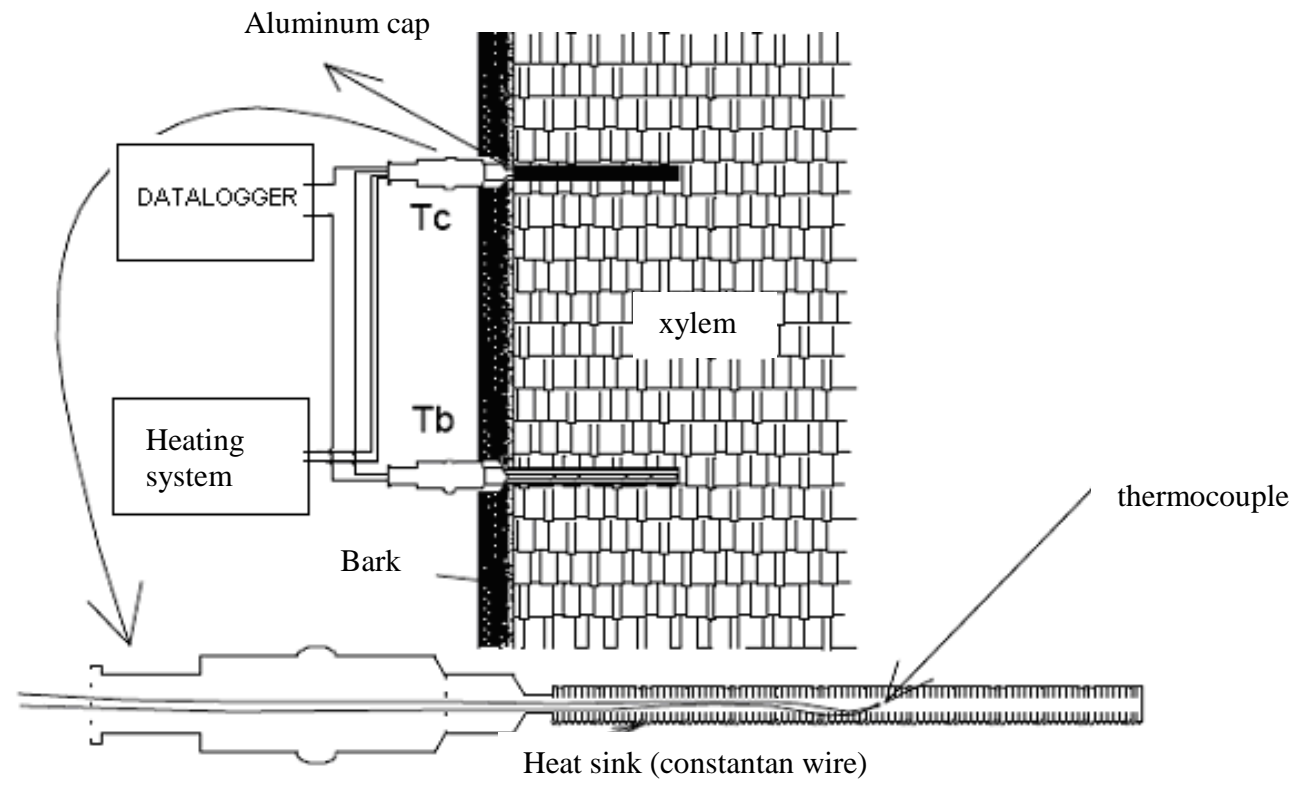

Source: DELGADO-ROJAS (2003).

FIGURE 1. Schematic of the thermal dissipation sensor.

The power to be applied to the upper probe $(\mathrm{Tc})$ recommended is $0.1 \mathrm{~W}$ per $\mathrm{cm}$ long of the probe. Were constructed of adjustable current sources to control the power dissipated in each sensor. The current source has the advantage, compared to the voltage source, to maintain constant power in the probe when electric resistance of copper varies with temperature.

Considering a condition of thermal equilibrium of the system (probe, stem and sap) to a constant flux density, it can be assumed that the input of heat (Joule) equals the heat dissipated by conduction and convection to the wall of the probe, as eq.(1): 


$$
\mathrm{hS}(\mathrm{Tc}-\mathrm{Tb})=\mathrm{P}
$$

In which,

$\mathrm{h}$ - heat transfer coefficient, $\mathrm{W} \mathrm{m}^{-2}{ }^{\circ} \mathrm{C}^{-1}$;

$\mathrm{S}$ - transfer surface area, $\mathrm{m}^{2}$;

Tc - probe temperature, ${ }^{\circ} \mathrm{C}$;

$\mathrm{Tb}$ - stem temperature in the absence of heating, ${ }^{\circ} \mathrm{C}$;

$\mathrm{P}$ - Electrical power applied, W.

The heat transfer coefficient $(h)$ depends on the specific mass $(\rho)$, the dynamic viscosity $(\mu)$, the specific heat $\left(c_{p}\right)$, and the thermal conductivity $(k)$ of the fluid. It also depends on the flow velocity (v) and the diameter of the transverse flow section (D). The relation between these variables applied to heat exchangers is shown in eq.(2):

$$
\mathrm{Nu}=\mathrm{C} \operatorname{Re}^{\mathrm{n}} \operatorname{Pr}^{\mathrm{m}}
$$

In which,

$$
\begin{aligned}
& \mathrm{Nu}=\frac{\mathrm{hD}}{\mathrm{k}}-\text { Nusselt number; } \\
& \mathrm{Re}=\frac{\rho \mathrm{pD}}{\mu}-\text { Reynolds number; } \\
& \mathrm{Pr}=\frac{\mu \mathrm{c}_{\mathrm{p}}}{\mathrm{k}}-\text { Prandtl number (for water }=4.6 \text { ), and } \\
& \mathrm{C}, \mathrm{n} \text { and } \mathrm{m}-\text { empirical coefficients. }
\end{aligned}
$$

The density of sap flow may be related to the coefficient $\mathrm{h}$ in eq.(3), which is derived from eq.(4), given $\rho, \mu, c p, k$ and $D$ constant; making the velocity equal to the density of sap flow - $F_{d}$ $\left(\mathrm{m}^{3} \mathrm{~m}^{-2} \mathrm{~s}^{-1}\right)$, and $\alpha$ is equal to $C \operatorname{Pr}^{\mathrm{m}}$, and $\beta$ equal to the coefficient $\mathrm{n}$ of eq.(2):

$$
h=h_{0}\left(1+\alpha F_{d}^{\beta}\right)
$$

In which,

$\mathrm{h}_{0}$ - heat transfer coefficient at null flow $\left(\mathrm{W} \mathrm{m}^{-2}{ }^{\circ} \mathrm{C}^{-1}\right)$, calculated by eq.(4):

$$
\mathrm{h}_{0}=\frac{\mathrm{RI}^{2}}{\mathrm{~S}\left(\mathrm{~T}_{\max }-\mathrm{T}_{\mathrm{f}}\right)}
$$

In which,

$\mathrm{R}$ - electrical resistance of heater element, $\Omega$;

I - electric current, A, and

$\mathrm{T}_{\text {máx }}$ - tempeture at null flow, only when heat loss by conduction occurs.

Combining eq.(1), (3) e (4):

$$
F_{d}=\left[\frac{1}{\alpha} \frac{\left(T_{m a x}-T_{f}\right)-\left(T-T_{f}\right)}{\left(T-T_{f}\right)}\right]^{\frac{1}{\beta}}=\left[\frac{1}{\alpha} \frac{\left(\Delta T_{\max }-\Delta T\right)}{\Delta T}\right]^{\frac{1}{\beta}}=\left[\frac{1}{\alpha} \mathrm{K}\right]^{\frac{1}{\beta}}
$$

GRANIER (1985) related the sap flow density $(\mathrm{Fd})$ and the temperature difference $(\Delta \mathrm{T})$ between the two probes, and validated this relation for some species, particularly woody plants like Pinus nigra, Pseudotsugamenziensii and Quercuspedunculata (conifers and porosity ring). 


$$
\begin{aligned}
& \mathrm{K}=\frac{\left(\Delta \mathrm{T}_{\min }-\Delta \mathrm{T}\right)}{\Delta \mathrm{T}}=\alpha \mathrm{F}_{\mathrm{d}}^{\beta}=0,020610^{-6} \mathrm{~F}_{\mathrm{d}}^{0,812} \\
& \mathrm{~F}_{\mathrm{d}}=118,9910^{-6}\left(\frac{\Delta \mathrm{T}_{\max }-\Delta \mathrm{T}}{\Delta \mathrm{T}}\right)^{1,231}
\end{aligned}
$$

The sap flow $-\mathrm{F}\left(\mathrm{m}^{3} \mathrm{~s}^{-1}\right)$ is calculated based on the effective section area of the xylem which leads to the crude sap - AS $\left(\mathrm{m}^{2}\right)$, or:

$$
\mathrm{F}=118,9910^{-6} \mathrm{~K}^{1,231} \mathrm{AS}
$$

\section{Construction and installation of the probes}

The probes were constructed of $1 \mathrm{~cm}$ long using Copper Constantan Thermocouples of $0.5 \mathrm{~mm}$ diameter, inserted into stainless steel needles of $1.0 \mathrm{~mm}$ internal diameter, which were filled with epoxy resin for fixing. For installation of the probes, two holes were made in the stem ( $5 \mathrm{~cm}$ above the graft and $10 \mathrm{~cm}$ equidistant) with diameters equal to the capsules that covered the external part of the probes to be inserted. The capsules of aluminum had an equal length to the probe, and internal diameter of $1.5 \mathrm{~mm}$. The probes were coated with thermal grease for better heat conduction, and inserted into the capsule. To ensure good fixation of the probe in the capsule, silicone was applied externally. After installation of the probes, the stem segment containing the probes was coated above and below with aluminum foil and placed in the location of the sensor with a protection foil in the form of a skirt.

Measurements of thermal differences were performed every 30 seconds and the average readings were stored every 15 minutes, in system of acquisition and storage of data ("datalogger" CR1000 Campbell SCi.) associated with two channel multiplexers (AM 1632 Relay Multiplexer, Campbell SCi.).

\section{Natural thermal gradients}

The natural thermal differences (DTN) were measured with the unheated probes on January $13^{\text {th }}, 14^{\text {th }}$ and $15^{\text {th }}, 2010$. The natural thermal differences measured in the stem (DTN) were correlated to four probes installed, taken as reference, due to its provision in the experiment, to generate, by means of linear regression, estimation models for each stem segment monitored, as eq.(8).

$$
\mathrm{DTN}_{\mathrm{E}}=\mathrm{a} \mathrm{DTN}_{\mathrm{ref}}+\mathrm{b}
$$

In which:

$\mathrm{DTN}_{\mathrm{E}}$ - natural thermal difference estimated for each probe, ${ }^{\circ} \mathrm{C}$;

$\mathrm{DTN}_{\text {ref }}$ - natural thermal difference for the reference probe, ${ }^{\circ} \mathrm{C}$, and

a e b - empirical coefficients.

The thermal difference with the heated sensor was corrected by eq.(9):

$$
\Delta \mathrm{T}=\Delta \mathrm{T}_{\mathrm{m}}-\mathrm{DTN}_{\mathrm{E}}
$$

In which,

$\Delta \mathrm{T}$ - corrected current thermal difference, ${ }^{\circ} \mathrm{C}$;

$\Delta \mathrm{T}_{\mathrm{m}}$ - uncorrected thermal difference measured by the probe, ${ }^{\circ} \mathrm{C}$, and

$\mathrm{DTN}_{\mathrm{E}}$ - natural thermal difference estimated for each probe, ${ }^{\circ} \mathrm{C}$.

\section{Conductive section area of the stem}

The Granier method for estimating the sap flow requires knowledge of conductive section area in the stem (effective area of the xylem). In order to estimate the area of the conductive section, 
it was cut the branches and trunks of two plants. It was made images of tranverse sections, and the areas were delineated with the aid of a CAD program, as shown in Figure 2. The xylem area was connected to the outside diameter of the stem by polynomial regression. It was measured the diameter of the stem of the plants at the insertion of the upper probe and it was estimated the conductive area of the stem.

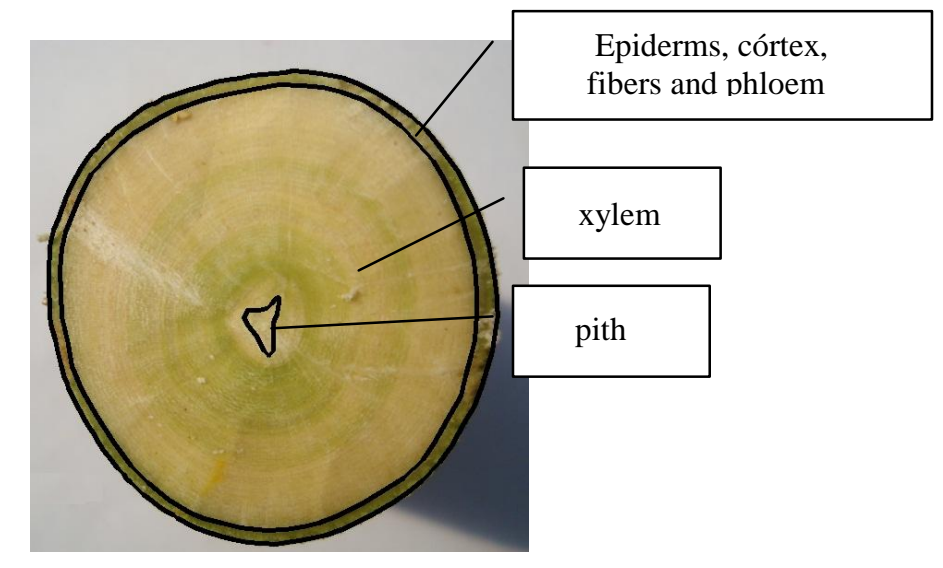

FIGURE 2. Transverse section of stems of 'Valencia' orange plant.

\section{Calibration}

In order to calibrate the equation to estimate the sap flow, lysimetric measurements were performed on a plant which better represented the mean sap flow of plants. The lysimeter soil surface was covered with the plastic bag to avoid evaporation losses. The angular coefficient of eq.(7) was adjusted by minimizing the absolute deviations between the sap flow accumulated in $24 \mathrm{~h}$ and the daily transpiration measured by lysimeter.

Measurements of weighing lysimeters were performed using a platform with four load cells and junction box, model AZ-9090-1T (Alfa Instruments), connected to the system acquisition and storage of data ("datalogger" CR1000 Campbell SCi.). For the calibration of the weighing lysimeter, masses of 1,000 and 5,000 grams were prepared using heavy bags of gravel on an analytical balance. The weighing system was calibrated according to the method applied for the calibration of a mass measuring system, by SANTOS et al. (2006).

The errors of repeatability, hysteresis and uncertainty of the lysimeter were $0.28 \mathrm{~kg}, 1.21 \mathrm{~kg}$ and $0.13 \%$, respectively. The repeatability was the factor that most interfered with the accuracy of the instrument. However, one should take into account that the repeatability error tends to be minimized under the conditions of operation in the field, as they are taken as averages of several readings.

Inside the greenhouse, it was monitored solar radiation through pyranometer (LP02-L12 Campbell Sci.), relative humidity and air temperature, by Vaisala Sensor (HMP45C-L12 Campbell Sci.) The sensors were installed at $2 \mathrm{~m}$ from the center of the greenhouse. The reference evapotranspiration - ETo $\mathrm{PM}_{\mathrm{PM}}\left(\mathrm{mm}^{-1}\right)$ was calculated by the standard method proposed by FAO Bulletin 56. As the speed of wind inside the greenhouse is very low, this value was set at $0.5 \mathrm{~m} \mathrm{~s}^{-1}$.

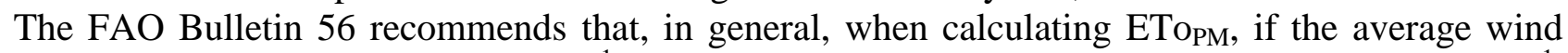
speed of $2 \mathrm{~m}\left(\mathrm{u}_{2}\right)$ is less than $0.5 \mathrm{~m} \mathrm{~s}^{-1}$, it should be considered to be a minimum value of $0.5 \mathrm{~m} \mathrm{~s}^{-1}$. This is necessary to consider the effects of instability of the limit layer and air fluctuation that promote the exchange of steam to the surface when the air is calm. This effect occurs when the wind speed is low and fluctuation of hot air causes the surface air exchange. Under these conditions, setting the $\mathrm{u}_{2}$ value of $0.5 \mathrm{~m} \mathrm{~s}^{-1}$ in the equation ETOPM, the accuracy of estimating improves (ALLEN et al., 1998). 


\section{RESULTS AND DISCUSSION}

\section{Conductive section area of the stem}

The relation between the conductive section area - $\mathrm{AS}\left(\mathrm{m}^{2}\right)$ and the outside diameter of the stem - D (m) obtained a good set of second degree polynomial equation (Eq. 10). The area occupied by the xylem represents an average of $84.75 \%, 14.5 \%$ by the shell, and by the bone $1.2 \%$ of the total area of the stem.

$$
\text { AS }=0,555 \mathrm{D}^{2}+0,807 \mathrm{D}-1,336\left(\mathrm{R}^{2}=0,999\right)
$$

FERNÁNDEZ et al. (2006) compared the anatomy of the xylem of sweet orange (Citrus sinensis $L$.) in the calibration of the heat pulse method. The authors state that the vessels are isolated or in radial chains 2-4, the parenchyma and vasicentric is more or less continuous, 2-5 tangential series of slots, the diameter of the lumen and the distances between the vessels are small enough to assume that the xylem is thermally homogeneous.

\section{Calibration}

Figure 3 shows the course of sap flow and transpiration calculated from time averages of three days, for the plant used for calibration. We may observe a large variation in the measurement of transpiration derived from lysimeter data. Despite the variation, it may be verify a lag between sap flow and transpiration. In the early morning hours, transpiration of the water stored occurs in plant tissues. At the end of the day, when transpiration tends to stop, the sap flow continues to occur in order to complete the tissue water lost through transpiration and not reset by the sap flow during the day.

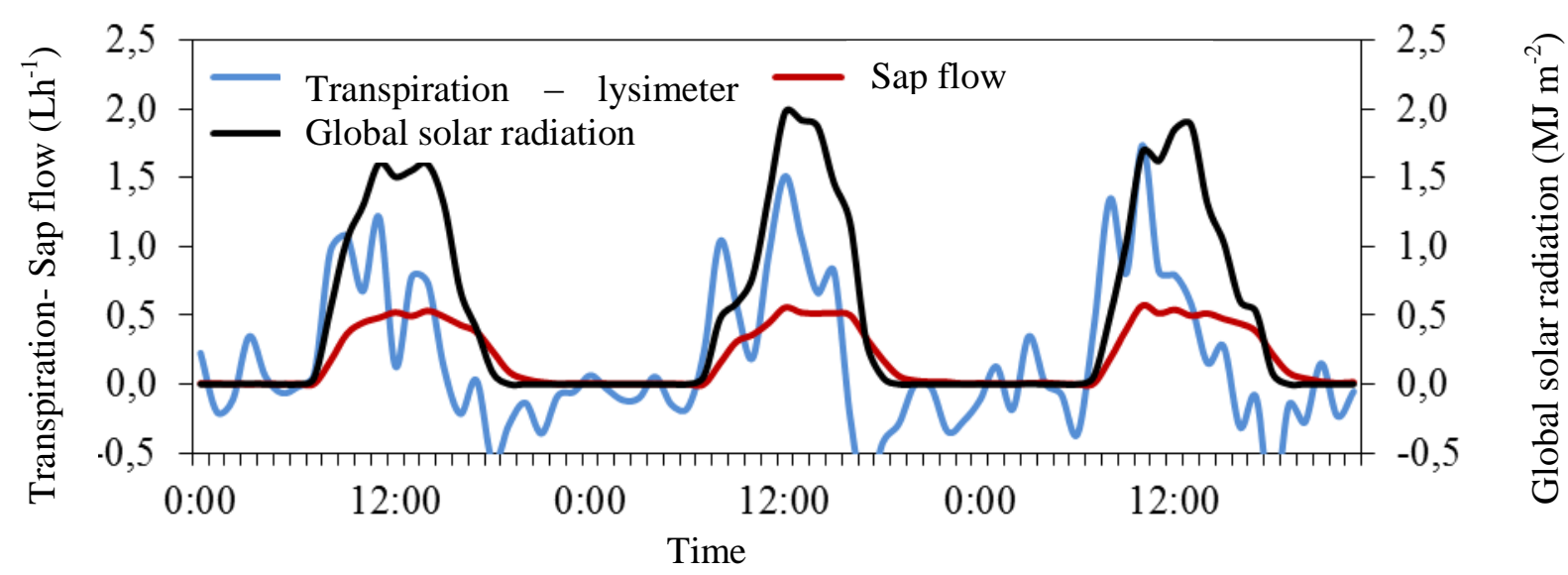

FIGURE 3. Course of solar radiation, transpiration and sap flow, calculated in hourly averages (Piracicaba, state of São Paulo, April $7^{\text {th }}$ to $\left.9^{\text {th }}, 2010\right)$.

Given the variation in lysimeter measures in time scale and the lag between sap flow and transpiration, it was chose to modify the linear coefficient of the general equation of Granier approaching the values on a daily scale according to Eq. (11). The coefficient $\beta$ (1.231) of Eq. (11) derived from Eq. (7) was kept at value set by GRANIER (1985). ALMEIDA (2007) stands in his study on heat dispersion in porous environment which, surprisingly, is found experimentally weak dependence of the dispersion of heat with the Reynolds number.

$$
\mathrm{F}=0,000594 \mathrm{~K}^{1,231} \text { AS }
$$

Figure 4 shows the relation between transpiration measurements made with lysimeter and sap flow calculated by Eq. (11) and by the general equation of Granier (Eq. 7). The average deviation between the sap and transpiration flow on a daily scale during the study period was $9.8 \%$. 


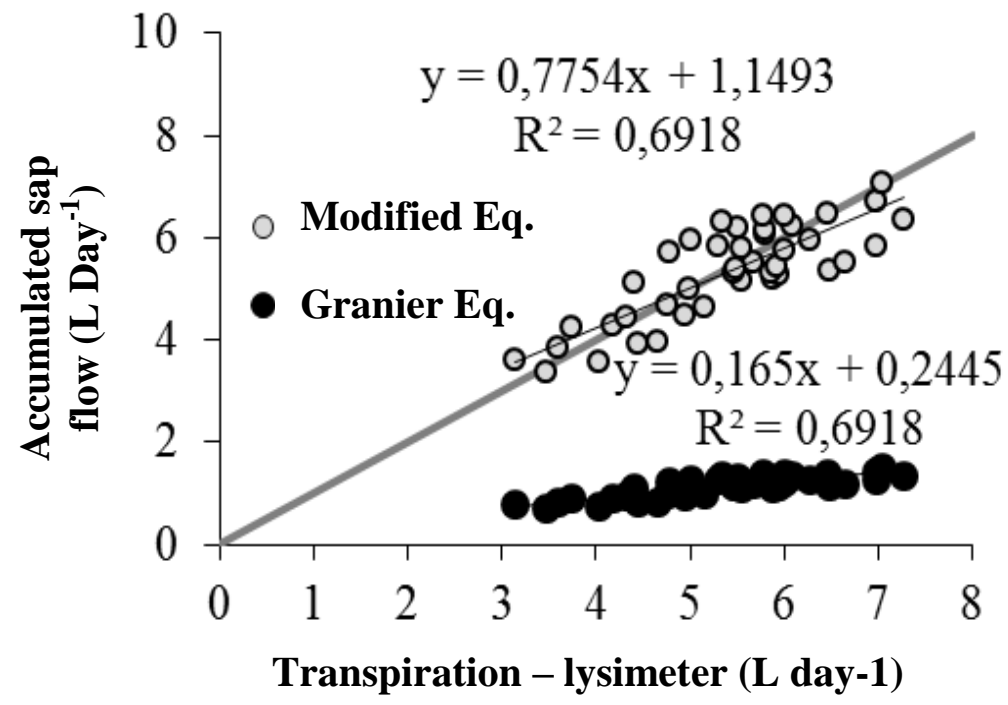

FIGURE 4. Relation between transpiration flow measurements with lysimeter and sap flow accumulated daily by the heat dissipation probe (Piracicaba, March $4^{\text {th }}$ to May $21^{\text {st }}$, 2010).

\section{Natural thermal gradients}

The Pearson correlation coefficients between the natural thermal differences presented in each stem of 40 plants monitored with the four reference probes showed good correlation. A reference probe was chosen for each plant according to the highest correlation coefficient. It was observed that with only two probes as reference probes the correlation coefficients were greater than 0.85 .

Despite the good correlation between the natural thermal differences, the direct subtraction of values measured by an unheated sensor installed in another plant or branch, of those registered with the heated probe, it must be observe cautiously, given the spatial variability. Table 1 presents the mean, maximum and minimum values of the average and range of stem natural thermal differences (DTN) of plants monitored, and the coefficients of eq.(8). There is a discrepancy between the values of average and range. The angular and linear coefficients of the equations were also quite different.

TABLE 1. Mean, maximum and minimum values of the average and range of stem natural thermal differences (DTN) of the plants monitored, and angular and linear coefficients of the linear regressions of DTN estimates.

\begin{tabular}{lccc}
\hline & Maximum Value & Minimum Value & Mean Value \\
\hline Average of DTN $\left({ }^{\circ} \mathrm{C}\right)$ & 0.122 & -0.217 & -0.078 \\
Range of DTN $\left({ }^{\circ} \mathrm{C}\right)$ & 1.799 & 0.373 & 1.114 \\
Angular coefficient & 1.908 & 0.694 & 1.269 \\
Linear coefficient & 0.234 & -0.131 & 0.005 \\
\hline
\end{tabular}

Figure 5 correlates the sap flow mean from the plants with compensation, with the flow mean without compensation of DTN, estimated by eq.(11). There was a trend towards underestimation of the method with uncompensated DTN, mainly for flow rates above $2.0 \mathrm{~L} \mathrm{day}^{-1}$. In the studied period, the average underestimation could reach $30.89 \%$. 


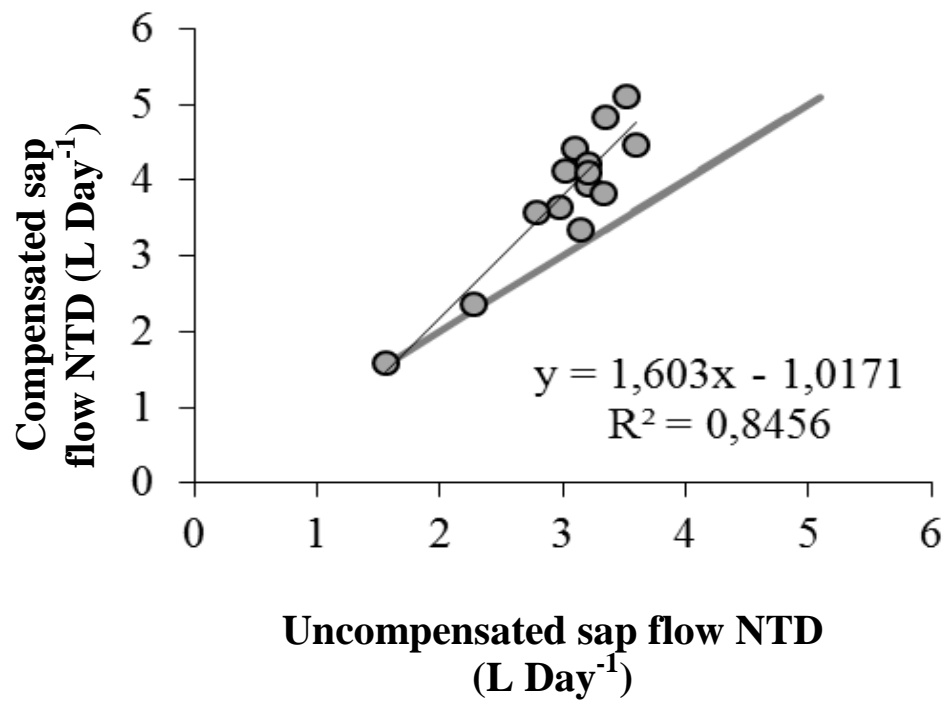

FIGURE 5. Relation between mean daily sap flow with and without compensation of stem natural thermal differences (DTN) - Piracicaba, January $17^{\text {th }}$ to $30^{\text {th }}, 2010$.

In order to evaluate the method used to minimize the effects of natural thermal gradients in the estimation of sap flow; this was correlated with the reference evapotranspiration (Figure 6). The best fit to the data was a logarithmic equation, probably due to the characteristics of citrus and the leaf conductance to vapor diffusion. When it was fix the thermal differences by subtracting the estimated natural thermal differences, the trend of underestimation of flow by the method decreases as shown by the fitted curves. The correction of the differences increases the precision of the method for estimating sap flow, as may be seen by the increase of the coefficient of determination $\left(\mathrm{R}^{2}\right)$ of the curve.

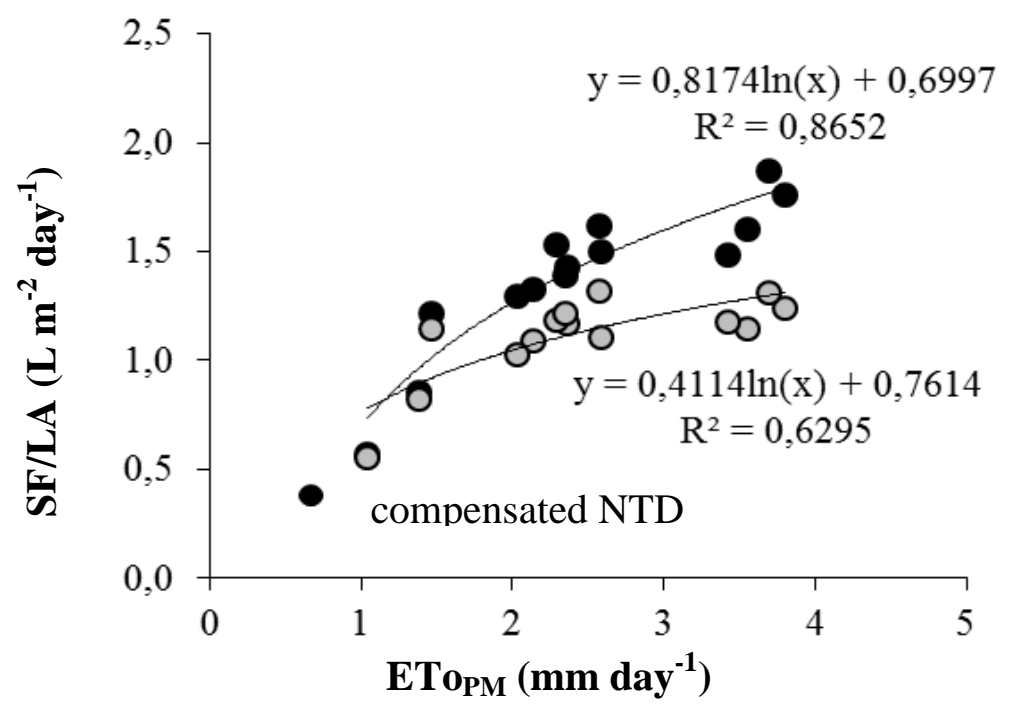

FIGURE 6. Mean sap flow per unit of leat area (FS / AF) of 40 'Valencia' oranges plants in function of daily reference evapotranspiration $\left(\mathrm{ETO}_{\mathrm{PM}}\right)$ - Piracicaba, January $17^{\text {th }}$ to $30^{\text {th }}, 2010$.

\section{CONCLUSIONS}

The Thermal Dissipation Probe Method, adjusting the original calibration and correcting the natural thermal gradient of the stem, was effective in the evaluation of transpiration (average absolute deviation of less than $10 \%$ ), providing data that enable the study of water relations of orange young plants. 


\section{ACKNOWLEDGEMENT}

The authors thank the Ministry of Science and Technology (MCT), the National Council for Scientific and Technological Development (CNPq) and Foundation for Research Support of São Paulo (FAPESP), for financially supporting this research through the Nacional Institute of Science and Technology in Irrigation Engineering (INCTEI).

\section{REFERENCES}

ALLEN, R.G.; PEREIRA, L.S.; RAES, D.; SMITH, D. Crop evapotranspiration: Guidelines for computing crop water requirements. Rome: FAO, 1998. 300 p. (Irrigation and Drainage Paper, 56.)

ALMEIDA, A.G. Aspectos computacionais do cálculo de dispersão de calor em meios porosos. 2007. 129 f. Dissertação (Mestrado em Computação) - Universidade Federal Fluminense, Niterói, 2007.

COELHO FILHO, M.A.; ANGELOCCI, L.R.; CAMPECHE, L.F.S.M.; FOLEGATTI, M.V.; BERNARDES, M.S.B. Field determination of young acid lime plants transpiration by the stem heat balance method. Scientia Agricola, Piracicaba, v.62, n.3, p.240-247, 2005.

DELGADO-ROJAS, J.S. Avaliação do uso do fluxo de seiva e da variação do diâmetro do caule e de ramos na determinação das condições hídricas de citrus, como base para o manejo de irrigação. 2003. 110f. Tese (Doutorado) - Escola Superior de Agricultura "Luiz de Queiroz", Piracicaba, 2003.

DELGADO-ROJAS, J.S.; ANGELOCCI, L.R.; FOLEGATTI, M.V. ; COELHO FILHO, M.A. Desempenho da sonda de dissipação térmica na medida da transpiração de plantas jovens de Lima Ácida. Engenharia Agrícola, Jaboticabal, v.27, n.2, p.404-413, 2007.

FERNÁNDEZ, J. E.; DURÁN, P. J.; PALOMO, M. J.;. DIAZ-ESPEJO, A.; CHAMORRO, V.; GIRÓN, I. F. Calibration of sap flow estimated by the compensation heat pulse method in olive, plum and orange trees: relationships with xylem anatomy. Tree Physiology, Victoria, v.26, p.719728, 2006.

GRANIER, A. Une nouvelle methode pour la measure du flux de seve brute dans le tronc des arbres. Annales Sciences Forestieres, Versailles, v.42, n.2, p.193-200, 1985.

SANTOS, A.O.; BERGAMASCHI, H.; ROSA, L.M.G.; BERGONCI, J.I.; RADIN, B. Assessment of corn water uptake based on sap heat tracing, under water-stressed conditions. Revista Brasileira de Engenharia Agrícola e Ambiental, Campina Grande, v.3, n.2, p.145-149, 1999.

SANTOS, R.M.; OLIVEIRA, A.S.; VELLAME, L.M.; BRANDÃO, F.J.C. Montagem e acurácia de um sistema experimental de pesagem para calibração de sensores de umidade do solo. Ciência e Agrotecnologia, Lavras, v.30, n.6, p.1162-1169, 2006.

SUGIURA, H.; SAKAMOTO, D.; SUGIURA, T.; ASAKURA, T.; MORIGUCHI, T. Evaluation of the use of the Granier sap flow method in japanese pear by comparison with transpiration by the weighing method, Acta Horticultural, Leuven, v.46, p.121-126, 2009.

VELLAME, L.M.; COELHO FILHO, M.A.; PAZ, V.P.S. Transpiração em mangueira pelo método Granier. Revista Brasileira de Engenharia Agrícola e Ambiental, Campina Grande, v.13, n.5, p.516523, 2009.

VELLAME, L.M.; COELHO FILHO, M.A.; PAZ, V.P.S.; COELHO, E.F. Stem heat balance method to estimate transpiration of young orange and mango plants. Revista Brasileira de Engenharia Agrícola e Ambiental, Campina Grande, v.14, n.6, p.594-599, 2010. 